\title{
Soil carbon dioxide efflux in pure and mixed stands of oak and beech
}

\author{
Mathieu JONARD*, Frédéric ANDRÉ, François JonARD, Nicolas MouTON, Pierre Procès, \\ Quentin PONETTE
}

Université catholique de Louvain, Faculté d'Ingénierie Biologique, Agronomique et Environnementale, Unité des Eaux et Forêts, Croix du sud 2/009, 1348 Louvain-la-Neuve, Belgique

(Received 5 May 2006; accepted 7 June 2006)

\begin{abstract}
Total Soil Respiration (TSR) was measured in pure and mixed stands of oak and beech and was partitioned into two contributions using the forest floor removal technique: Mineral Soil Respiration (MSR) and Forest Floor Respiration (FFR). In addition, laboratory incubations of the forest floor and the Ah horizon were performed to evaluate the heterotrophic respiration and the DOC production of these horizons. The relationships between soil temperature and the various soil respiration contributions in the three stands were compared using $Q_{10}$ functions. In situ, significant differences $(\alpha=0,05)$ between stands were observed for the $R_{10}$ parameter (respiration rate at $10{ }^{\circ} \mathrm{C}$ ) of the TSR, MSR and FFR contributions, while only the temperature sensitivity $\left(Q_{10}\right)$ of TSR was significantly affected by stand composition. The effect of soil water content was only significant on MSR and followed different patterns according to stand composition. Under controlled conditions, the $R_{10}$ of the forest floor and of the Ah horizon varied with stand composition and the $Q_{10}$ of the forest floor decreased in the order: oak (2.27) > mixture (2.01) > beech (1.71).
\end{abstract}

soil respiration / partitioning / species effect / mixed stand / abiotic factors

Résumé - Flux de $\mathrm{CO}_{2}$ en provenance du sol en peuplements purs et mélangés de chêne et de hêtre. La respiration totale du sol (RTS) a été mesurée en peuplements purs et mélangés de chêne et de hêtre et a été subdivisée en deux contributions en enlevant les couches holorganiques de certaines zones de mesure (RSM : respiration du sol minéral et RCH : respiration des couches holorganiques). De plus, des échantillons de couches holorganiques et d'horizon Ah ont été incubés en laboratoire pour évaluer la respiration hétérotrophique et la production de DOC de ces horizons. Des fonctions $Q_{10}$ ont été utilisées pour comparer les trois peuplements au niveau de la réponse à la température des différentes contributions à RTS. In situ, des différences significatives $(\alpha=0.05)$ entre peuplements ont été mises en évidence en ce qui concerne le paramètre $R_{10}\left(\right.$ flux à $\left.10^{\circ} \mathrm{C}\right)$ de toutes les contributions (RTS, RSM, RCH) et la sensibilité à la température $\left(Q_{10}\right)$ de RTS uniquement. L'effet de la teneur en eau du sol était seulement significatif sur RSM et variait en fonction de la composition spécifique du peuplement. En conditions contrôlées, le paramètre $R_{10}$ des couches holorganiques et de l'horizon Ah était significativement influencé par la composition spécifique; la respiration hétérotrophique des couches holorganiques présentait une sensibilité à la température décroissant suivant l'ordre : chênaie $(2,27)>$ mélange $(2,01)>$ hêtraie $(1,71)$

respiration du sol / effet espèce / peuplement mélangé / facteurs abiotiques

\section{INTRODUCTION}

The annual variation of $\mathrm{CO}_{2}$ released from the soil has been measured in a large variety of ecosystems [38]. These studies have shown that soil respiration is mainly controlled by soil temperature and soil moisture [14, 23, 37]. Therefore several authors have hypothesized that global warming and changes in rainfall amount and distribution might influence soil respiration and the capacity of the soil to sequester carbon $[38,45]$. However, recent studies have found soil respiration to be mainly driven by newly produced photosynthates and weather conditions $[3,18,19,26]$.

Soil respiration is the sum of two components, livingroot respiration (autotrophic respiration) and organic matter decomposition (heterotrophic respiration) [25]. However, to evaluate whether or not soils are sources or sinks of carbon, only heterotrophic respiration is taken into account and compared to above-ground and below-ground litter productions

\footnotetext{
*Corresponding author: jonard@efor.ucl.ac.be
}

[25]. Soil respiration may also be partitioned into several contributions according to the soil horizon from which $\mathrm{CO}_{2}$ is produced. Separating the forest floor contribution from that of the mineral soil is important since the forest floor contains more labile carbon pools, which could therefore respond differently to abiotic factors and be more affected by climatic changes [7].

Various approaches have been used to quantify the different sources of soil $\mathrm{CO}_{2}$ emissions and were classified by Hanson et al. [25] in three categories: component integration, root exclusion and isotopic methods. To isolate the forest floor contribution in the field, different methods of component integration were employed: litter addition [8], forest floor removal [39], forest floor replacement by non-biodegradable litter [22] and forest floor separation by a plexiglass sheet [17].

In this study, we used the forest floor removal method combined with laboratory incubations of the forest floor and the Ah horizon. The objective was to evaluate the impact of stand composition on the soil respiration components and contributions, and on their response to abiotic factors (soil temperature and soil water content). 
Indeed, species might affect soil respiration components and contributions through its influence on litter production and decomposition $[4,9,41]$, on rooting patterns, root dynamics [43] and root photosynthate allocation [3], and on soil microclimate [2]. In addition, interactions between species in mixed stands have been reported in some instances [40], which might affect soil respiration.

\section{MATERIALS AND METHODS}

\subsection{Study site and stands}

The study site is located in the western part of the Belgian Ardennes at $300 \mathrm{~m}$ elevation $\left(50^{\circ} 01^{\prime} \mathrm{N}, 4^{\circ} 24^{\prime} \mathrm{E}\right)$. The average annual rainfall is slightly above $1000 \mathrm{~mm}$ and the mean annual temperature is $8{ }^{\circ} \mathrm{C}$. In 2003 , however, the year during which most of the in situ respiration measurements were taken, precipitation was $756 \mathrm{~mm}$ and mean annual temperature was $9.8^{\circ} \mathrm{C}$. The forest (60 ha) consists of common oak (Quercus petraea LIEBL.) and European beech (Fagus sylvatica L.) and lies on acid brown earth soil (USDA: Dystrochrepts) with a moder humus and an $\mathrm{A}_{h} \mathrm{~B}_{w} \mathrm{C}$ profile.

Three experimental plots were installed in stands dominated either by oak ( $0.65 \mathrm{ha})$ or by beech $(0.63 \mathrm{ha})$ and in a $1: 1$ mixture of both species $(0.53 \mathrm{ha})$. These plots are all situated on the same tableland (305-312 m) and were selected in such a way that stand composition was the main varying factor. The beech and the mixed stands are located side by side while the oak plot is $600 \mathrm{~m}$ away from them. Soil homogeneity was evaluated on the basis of a detailed characterization of two soil profiles ( $\mathrm{pH}$, granulometry, exchangeable cations, total pools). In addition, six samples of the Ah horizon were taken in each stand to further check the similarity of soil characteristics between stands ( $\mathrm{pH}$, exchangeable cations, total pools). The main soil difference is the stone content below $20 \mathrm{~cm}$ depth which is higher in the beech and mixed stands. The soils of all stands are well drained; the ground water is below $1.5 \mathrm{~m}$ depth during the growing season and rises in winter up to $30-45 \mathrm{~cm}$ depth. In each stand, all trees were measured (stem circumference at a height of $1.3 \mathrm{~m}$, total tree height) and positioned (coordinates) in 2001 (Tab. I).

\subsection{Litter collection}

In August 2001, 61 litter traps $(0.7 \times 0.7 \mathrm{~m})$ were placed in the three stands ( $n=21,17$ and 23 respectively in the oak, mixed and beech stands). Litterfall was collected once a year after leaf shedding in 2001, 2002 and 2003. The collected samples were air-dried, sorted into leaves and other litter materials. All components were weighed and sub-samples were oven-dried at $65{ }^{\circ} \mathrm{C}$ during $48 \mathrm{~h}$ in order to convert fresh weight into dry weight. Then, the carbon content of the leaf samples was determined with an elemental analyser (FlashEA 1112 Series, Thermo Fisher Scientific, USA).

\subsection{Sampling of the forest floor and the hemiorganic horizon}

Sampling was carried out in six sub-plots per stand between 25 February and 5 March 2002. The different forest floor layers and the Ah horizon (depth: 1.5-2.5 cm) were collected separately according
Table I. Mean stand characteristics of the three experimental plots in 2001 (standard deviation between brackets).

\begin{tabular}{lccccc}
\hline Stand & Species & $\mathrm{N} / \mathrm{ha}$ & $\begin{array}{c}\mathrm{C}_{130}^{1} \\
(\mathrm{~cm})\end{array}$ & $\begin{array}{c}\text { Basal area } \\
\left(\mathrm{m}^{2} \text { ha }^{-1}\right)\end{array}$ & $\begin{array}{c}\text { Dominant } \\
\text { height }^{2}(\mathrm{~m})\end{array}$ \\
\hline Oak & Hornbeam & 150 & $31(11)$ & 1.3 & \\
& Oak & 197 & $101(27)$ & 16.9 & 22.5 \\
Mixed & Beech & 125 & $46(36)$ & 3.4 & \\
& Oak & 101 & $108(19)$ & 9.7 & 24.0 \\
Beech & Beech & 135 & $101(35)$ & 12.3 & 25.5 \\
& Oak & 49 & $94(13)$ & 3.5 & \\
& Beech & 286 & $82(41)$ & 19.5 & 25.5 \\
\hline
\end{tabular}

${ }^{1}$ Stem circumference at a height of $130 \mathrm{~cm}$.

${ }^{2}$ Mean height of the hundred highest trees per ha.

to Jabiol et al. [27] using a template of $30 \times 30 \mathrm{~cm}$. The forest floor and Ah samples were air-dried and the Ah samples were sieved to a particle size of less than $2 \mathrm{~mm}$ before weighing. Sub-samples were oven-dried at $65{ }^{\circ} \mathrm{C}$ during $48 \mathrm{~h}$ in order to convert fresh weight into dry weight.

\subsection{Extraction of fine roots}

Root sampling was conducted in October and November 2004 in the vicinity of the experimental plots in ten triangular areas delimited by three adjacent trees. Three sampling areas were located in each of the quasi-pure stands dominated either by oak or beech and four were located in a mixture of both species.

The fine roots of the forest floor and of the Ah horizon were collected separately using a template of $30 \times 30 \mathrm{~cm}$ and small gardening tools (secateurs, sharp knife, shovel). In the laboratory, the root samples were first broadly separated from soil residues and then carefully cleaned using a $2 \mathrm{~mm}$ sieve and a water spray. Roots were sorted according to diameter (fine roots $<2 \mathrm{~mm}$ and coarse roots $\geqslant 2 \mathrm{~mm}$ ). Root components were oven-dried at $65{ }^{\circ} \mathrm{C}$ during $48 \mathrm{~h}$ and then weighed.

\subsection{Respiration and ground climate measurements}

The respiration measurements were taken bimonthly during one year (from 19 November 2002 to 6 November 2003) with a portable infrared gas monitor (PP Systems: EGM-1, UK) combined with a soil respiration chamber (PP Systems: SRC-1, UK) (for a detailed description of this method see [33]).

The respiration measurements were performed in three sub-plots per stand. In two oak and two beech sub-plots, additional measurements were made in adjacent zones exposed to two contrasting moisture treatments. The zones corresponding to the dry modality were obtained using roofs $\left(3 \times 2.5 \mathrm{~m}^{2}\right)$ and were watered every week with the same volume of throughfall water $(56 \mathrm{~L})$, except when the water tank was empty due to prolonged drought periods. During the measurement period, they received $311 \mathrm{~mm}$ per year. The zones of the moist modality were also watered weekly with the same water volume $(56 \mathrm{~L})$ in addition to the normal throughfall, resulting in a total of $762 \mathrm{~mm}$ per year. For both modalities, a watering can with a rose was used to deliver water gently. 
On all sampling dates $(n=25)$ and locations $(n=3$ stands $\times 3$ sub-plots +2 stands $\times 2$ sub-plots $\times 2$ modalities), three measurements were taken on the forest floor within a delimited area $(0.75 \times$ $1 \mathrm{~m})$ and three other measurements were taken in an adjacent area of the same size from which the forest floor had been permanently removed. We computed mean values per date and location and subtracted the mean flux obtained on the area without forest floor (Mineral Soil Respiration, MSR) from that measured on the forest floor (Total Soil Respiration, TSR) in order to obtain the Forest Floor Respiration (FFR). As the TSR and MSR measurements were not made exactly at the same place, the subtraction (TSR-MSR) provided some negative FFRs given the large spatial variability. In addition, this approach to partition TSR into mineral soil and forest floor components could produce artefacts since the forest floor removal could affect the temperature and moisture budget of the mineral soil as well as the gas diffusion within it.

In all the sub-plots and for all moisture modalities, soil temperature and volumetric soil water content were measured hourly, using probes (thermocouples for soil temperature and TDR for soil water content, Campbell Scientific Inc.: CS615) inserted in the Ah horizon at about $2 \mathrm{~cm}$ below the base of the holorganic layers. The monitoring of ground climate was carried out in the undisturbed areas (with forest floor) during the whole period of respiration measurements.

\subsection{Incubation-leaching experiments}

The forest floor and the Ah horizon were collected on areas of $1 \mathrm{~m}^{2}$ in the vicinity of the oak, mixed and beech plots, just after leaf fall in December 2004. The different layers of the forest floor were collected separately, according to Jabiol et al. [27]. Then the samples were processed the same way as previously described for the first sampling (see Sect. 2.3).

Sample containers were made from plastic tubing (length $=30 \mathrm{~cm}$, $\varnothing=15.5 \mathrm{~cm}$ ). The bottom end was covered with a fine plastic mesh $(20 \mu \mathrm{m})$ and supported by a perforated plate extended by a piece of small rubber tubing closed with Mohr pliers. The containers were filled with either forest floor or Ah materials. The forest floor containers were filled with materials from the different layers in order to obtain the same weight/surface ratios as those observed in the field, while the Ah containers were filled with a fixed amount of Ah material (31g d.w.). Before starting the incubations, the forest floor of all the containers was leached with MilliQ water according to a soil:solution ratio of 1:20 and the Ah horizon was leached with $200 \mathrm{~mL}$ of MilliQ water. After adjustment of soil moisture to water holding capacity, two open dishes, one with $50 \mathrm{~mL}$ of $1 \mathrm{M} \mathrm{NaOH}$ and the other with $50 \mathrm{~mL}$ of MilliQ water, were placed on the soil surface and the containers were closed and made airtight.

The two types of containers were incubated at three different temperatures $\left(4,10\right.$ and $\left.18{ }^{\circ} \mathrm{C}\right)$ during four weeks. In total, 54 containers were used ( 3 replicates $\times 3$ temperatures $\times 2$ horizons $\times 3$ stands) plus a series of blanks without any soil material. Every week, the containers were opened for titration and replacement of the $\mathrm{NaOH}$ solutions as well as for moisture content adjustment. The respiration rates at the three temperatures were computed without considering the first incubation week in order to avoid the initial flush of mineralization [5]. At the end of the experiment, another leaching was carried out and the DOC content of the leachates was measured with a Dohrman DC-180 C analyser.

In order to compare the respiration rates observed in situ $\left(\mathrm{g} \mathrm{m}^{-2} \mathrm{~h}^{-1}\right)$ with those obtained by incubation, the mean specific rates $\left(\mathrm{g} \mathrm{g}^{-1} \mathrm{~h}^{-1}\right)$ measured in the laboratory were multiplied by the mass $\left(\mathrm{g} \mathrm{m}^{-2}\right)$ of the samples collected in the field. Six respiration rate values were thus obtained per horizon and per stand for each incubation temperature.

\subsection{Mathematical and statistical analyses}

The study design does not allow us to test the stand composition effect as there is only one stand of each species composition $(N=1)$; however, we can still test for stand differences ( $N=3$ sub-plots). In the following sections, we discuss the stand effect as a species composition effect and assume it was the main varying factor between stands (see Sect. 2.1).

One-way ANOVAs were conducted to test the impact of stand on litterfall, on forest floor and Ah mass, and on root abundance. To see whether the temporal pattern of the abiotic factors differed between stands and between moisture modalities, we used a linear mixed model with two random factors ('date' and 'location') and multiple comparison tests (Tukey).

From the field and laboratory data, we analysed the relationships between soil temperature and the various soil respiration contributions, using a modified Van’t Hoff equation ( $Q_{10}$ function) [13].

$$
R=R_{10} \cdot Q_{10}^{\frac{(T-10)}{10}}
$$

where $R$ is the respiration rate $\left(\mathrm{g} \mathrm{m}^{-2} \mathrm{~h}^{-1}\right), R_{10}$ and $Q_{10}$ are parameters estimating respectively the respiration rate at $10{ }^{\circ} \mathrm{C}$ and the factor by which the respiration rate differs for a temperature interval of $10^{\circ} \mathrm{C}$, $T$ is the temperature $\left({ }^{\circ} \mathrm{C}\right)$. For the same soil respiration contribution, the $R_{10}$ and $Q_{10}$ parameters of the three stands were estimated separately and then compared on the basis of their variance, assuming they were normally distributed.

The effect of soil water content on the in situ soil respiration contributions was tested using a quadratic relationship, which was allowed to vary with stand composition. In addition, random effects were introduced in the model to account for the correlations between measurement made on the same date or at the same location.

$$
\ln (R)=a_{i}+b_{i} \cdot \theta+c_{i} \cdot \theta^{2}+\delta+\lambda+\varepsilon
$$

where $\theta$ is the soil water content $\left(\mathrm{m}^{3} \mathrm{~m}^{-3}\right), \delta$ and $\lambda$ are respectively the random effects 'date' and 'location' and $\varepsilon$ is the residual term.

The differences between moisture modalities in the oak and beech stands were tested, using contrasts in association with a linear mixed model containing the following variables: stand, moisture treatment, the interaction between stand and moisture treatment, and the two random effects 'date' and 'location'.

The models were all fitted with the MIXED procedure of the SAS software (Statistical Analysis System, Version 8.20, SAS Institute Inc., Cary, NC, USA), except the $Q_{10}$ functions which were fitted with the NLMIXED procedure.

\subsection{Computation methods for estimating the annual fluxes}

The annual fluxes for TSR, MSR and FFR (field measurements) and for the forest floor and Ah decomposition (laboratory incubations) were obtained by integrating daily values predicted by the models from the soil temperature time series. Total litterfall was estimated 
Table II. Leaf litterfall, mass of the forest floor and of the Ah horizon, and root abundance in the three stands. Differences between stands were tested using an ANOVA 1 and significance may be evaluated with the $P$ value. Numbers between brackets represent standard deviation.

\begin{tabular}{lccccc}
\hline Stand & $\begin{array}{c}\text { Leaf litterfall } \\
\left(\mathrm{g} \mathrm{m}^{-2} \mathrm{y}^{-1}\right)\end{array}$ & $\begin{array}{c}\text { Forest floor } \\
\left(\mathrm{g} \mathrm{m}^{-2}\right)\end{array}$ & $\begin{array}{c}\text { Ah } \\
\left(\mathrm{g} \mathrm{m}^{-2}\right)\end{array}$ & Forest floor root $\left(\mathrm{g} \mathrm{m}^{-2}\right)$ & Ah \\
\hline Oak & $288.9(38.4)$ & $789.2(116.1)$ & $9070(4597)$ & $2.1(3.9)$ & $30.8(12.4)$ \\
Mixture & $277.3(25.2)$ & $982.9(93.4)$ & $8624(3642)$ & $12.9(7.2)$ & $49.5(15.4)$ \\
Beech & $281.5(28.7)$ & $1548.2(190.5)$ & $6101(1493)$ & $15.2(10.1)$ & $40.6(17.6)$ \\
$P$ & 0.4900 & $<0.0001$ & 0.3121 & 0.0713 & 0.1321 \\
\hline
\end{tabular}

(a) Soil temperature

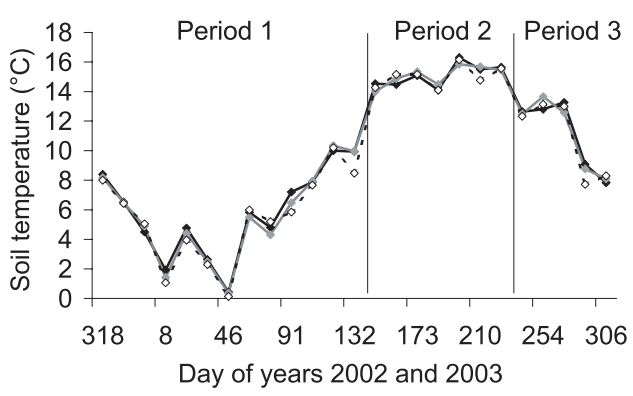

(c) Moisture treatment

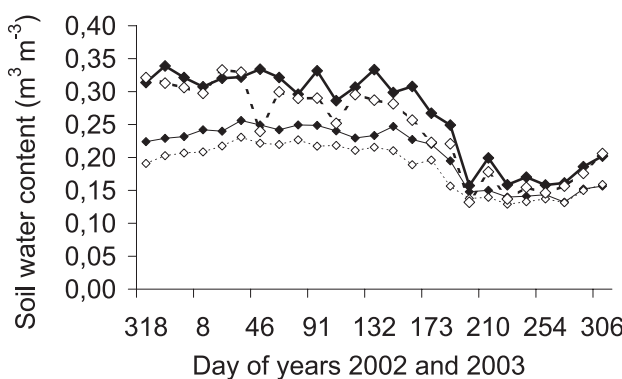

(b) Soil water content
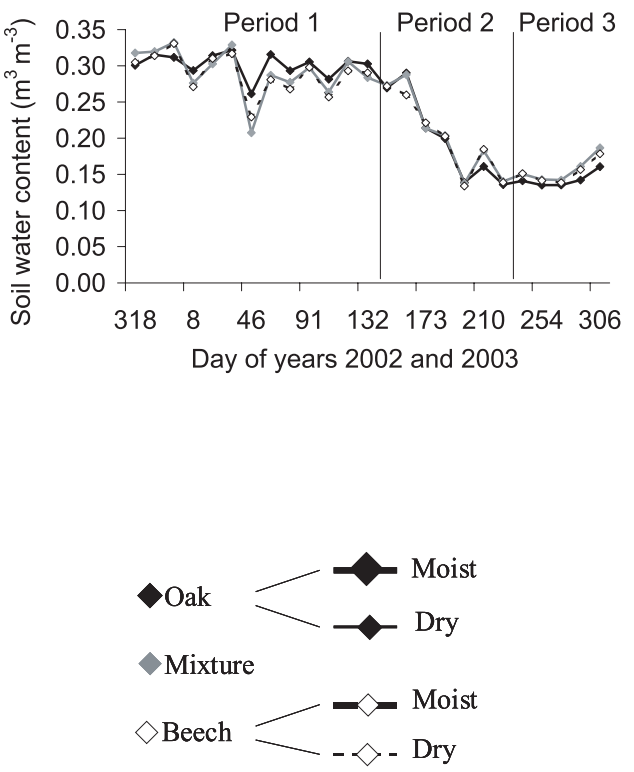

Figure 1. Temporal patterns of soil temperature (a) and soil water content (b) in the oak, mixed and beech stands (zones without moisture treatment, $n=3)$ and comparison of soil water content variations in the moist and dry modalities $(\mathrm{c}, n=2)$.

on the basis of the leaf litter amounts, considering that total litterfall was composed of $70 \%$ leaves and $30 \%$ non-leaf litter [10,32]. The annual fluxes of DOC were estimated using a mean value per stand computed by averaging the data obtained at the three temperatures (4, 10 and $18{ }^{\circ} \mathrm{C}$ ) since the influence of temperature on DOC production could not be modeled from our data.

\section{RESULTS}

\subsection{Leaf litterfall, mass of the forest floor and of the Ah horizon, and root abundance in the three stands}

Leaf litterfall was similar in the oak, mixed and beech stands ( $P=0.4900$, Tab. II). In contrast, the forest floor mass increased in the order: oak $<$ mixture $<$ beech $(P<0.0001$, Tab. II). Fine roots were more abundant in the beech forest floor compared with oak; however, this difference was not significant, although not far from the 5\% level of significance $(P=0.0713$, Tab. II). The average Ah mass of the oak and mixed stands was 50\% larger than that of the beech stand, but these differences between stands were not significant $(P=0.3121$, Tab. II) since the associated variability was very high, especially under oak. In the Ah horizon, we did not observe any stand effect on root abundance $(P=0.1321$, Tab. II). The fine root mass in the forest floor and in the Ah horizon was very low, suggesting that most of the fine roots were not extracted.

\subsection{Temporal patterns of abiotic factors}

The temporal patterns of soil temperature (Fig. 1 a) and soil water content (Fig. 1b) were very similar in all stands; soil temperature was however on average $0.23{ }^{\circ} \mathrm{C}$ lower under beech than under oak $(P=0.0089)$. In both the oak and beech stands, the temporal patterns of soil water content were significantly different in the two moisture modalities $(P<0.0001)$; soil water content was maintained at a higher level in the moist 
Table III. Parameters and $R^{2}$ of the $Q_{10}$ functions (Eq. (1)) estimated for the different soil respiration contributions in the three stands (standard error between brackets). Concerning field measurements, only zones without moisture treatment were considered. Different letters indicate statistically significant differences between stands $(P<0.05)$.

\begin{tabular}{|c|c|c|c|c|c|c|c|c|c|}
\hline & \multicolumn{3}{|c|}{$R_{10}\left(\mathrm{~g} \mathrm{~m}^{-2} \mathrm{~h}^{-1}\right)$} & \multicolumn{3}{|c|}{$Q_{10}$} & \multicolumn{3}{|c|}{$R^{2}$} \\
\hline & Oak & Mixture & Beech & Oak & Mixture & Beech & Oak & Mixture & Beech \\
\hline \multicolumn{10}{|l|}{ Field } \\
\hline TSR & $\begin{array}{c}0.35^{\mathrm{a}} \\
(0.009)\end{array}$ & $\begin{array}{c}0.29^{\mathrm{b}} \\
(0.009)\end{array}$ & $\begin{array}{c}0.29^{\mathrm{b}} \\
(0.009)\end{array}$ & $\begin{array}{l}3.19^{\mathrm{a}} \\
(0.18)\end{array}$ & $\begin{array}{l}3.31^{\mathrm{a}} \\
(0.23)\end{array}$ & $\begin{array}{l}4.26^{\mathrm{b}} \\
(0.29)\end{array}$ & 0.70 & 0.66 & 0.77 \\
\hline MSR & $\begin{array}{c}0.24^{\mathrm{a}} \\
(0.008)\end{array}$ & $\begin{array}{c}0.20^{\mathrm{b}} \\
(0.008)\end{array}$ & $\begin{array}{c}0.16^{\mathrm{c}} \\
(0.008)\end{array}$ & $\begin{array}{l}3.24^{\mathrm{a}} \\
(0.24)\end{array}$ & $\begin{array}{l}3.43^{\mathrm{a}} \\
(0.32)\end{array}$ & $\begin{array}{l}3.85^{\mathrm{a}} \\
(0.44)\end{array}$ & 0.50 & 0.57 & 0.59 \\
\hline FFR & $\begin{array}{c}0.10^{\mathrm{a}} \\
(0.010)\end{array}$ & $\begin{array}{c}0.09^{\mathrm{a}} \\
(0.010)\end{array}$ & $\begin{array}{c}0.13^{\mathrm{b}} \\
(0.011)\end{array}$ & $\begin{array}{l}2.80^{\mathrm{a}} \\
(0.67)\end{array}$ & $\begin{array}{l}2.89^{\mathrm{a}} \\
(0.70)\end{array}$ & $\begin{array}{l}4.65^{\mathrm{a}} \\
(0.83)\end{array}$ & 0.18 & 0.08 & 0.33 \\
\hline Laboratory & & & & & & & & & \\
\hline Ah horizon & $\begin{array}{c}0.09^{\mathrm{a}} \\
(0.012)\end{array}$ & $\begin{array}{c}0.08^{\mathrm{ab}} \\
(0.012)\end{array}$ & $\begin{array}{c}0.06^{\mathrm{b}} \\
(0.005)\end{array}$ & $\begin{array}{c}1.56^{\mathrm{a}} \\
(0.32)\end{array}$ & $\begin{array}{c}1.71^{\mathrm{a}} \\
(0.36)\end{array}$ & $\begin{array}{c}1.5^{\mathrm{a}} \\
(0.17)\end{array}$ & 0.22 & 0.29 & 0.43 \\
\hline Forest floor & $\begin{array}{c}0.07^{\mathrm{a}} \\
(0.004)\end{array}$ & $\begin{array}{c}0.07^{\mathrm{a}} \\
(0.002)\end{array}$ & $\begin{array}{c}0.08^{\mathrm{b}} \\
(0.003)\end{array}$ & $\begin{array}{l}2.27^{\mathrm{a}} \\
(0.17)\end{array}$ & $\begin{array}{l}2.01^{\mathrm{a}} \\
(0.09)\end{array}$ & $\begin{array}{l}1.71^{\mathrm{b}} \\
(0.09)\end{array}$ & 0.90 & 0.94 & 0.86 \\
\hline
\end{tabular}

All periods, no moisture treatment

Period 2, all moisture treatments

Total Soil Respiration
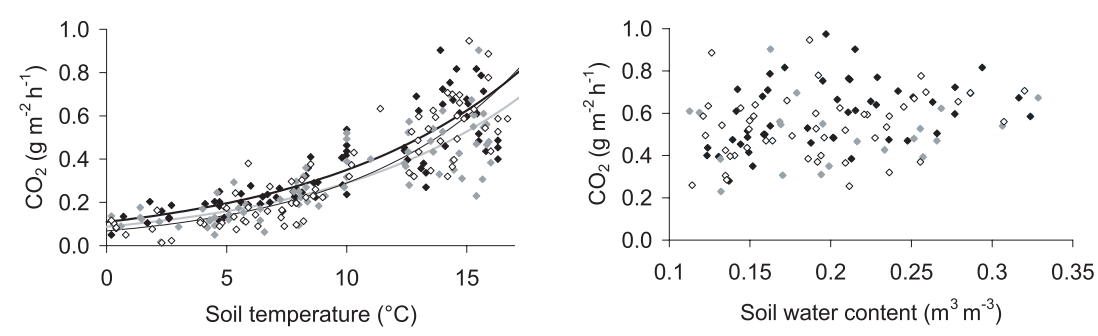

Mineral Soil Respiration
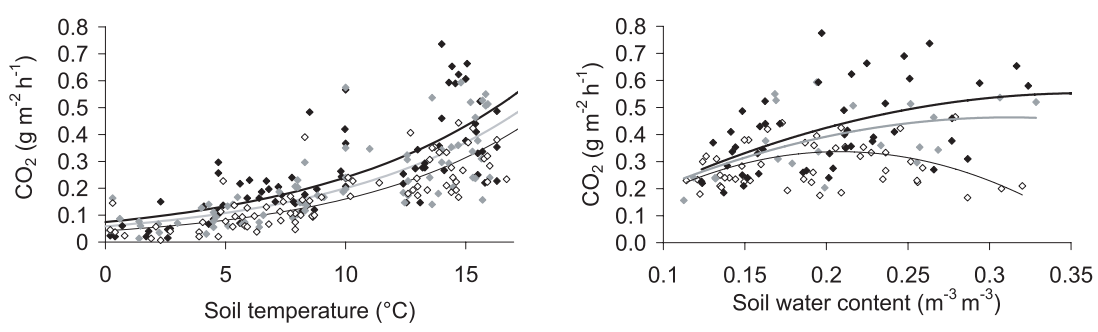

Forest Floor Respiration
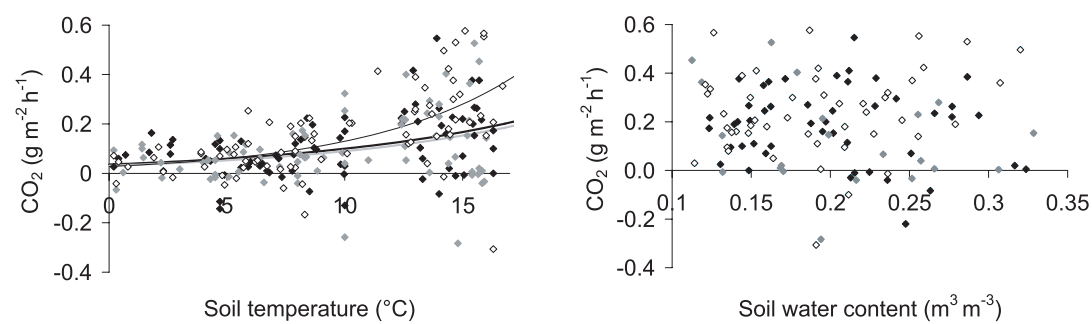

$\diamond$ Oak $-\Delta$ Mixture $-\diamond$ Beech -

Figure 2. Influence of stand composition on the relationships between the abiotic factors and the soil respiration contributions. Note the scale differences between the soil respiration contributions. Lines represent model predictions for the different stand composition. 
Table IV. Effect of the moisture treatment on the mean TSR, MSR and FFR. Differences between modalities (Moist-Dry) are expressed as percentage of the average value of the two modalities and their significance is given by the $P$-value.

\begin{tabular}{lcccc}
\hline & $\begin{array}{c}\text { Dry } \\
\left(\mathrm{g} \mathrm{m}^{-2} \mathrm{~h}^{-1}\right)\end{array}$ & $\begin{array}{c}\text { Moist } \\
\left(\mathrm{g} \mathrm{m}^{-2} \mathrm{~h}^{-1}\right)\end{array}$ & $\begin{array}{c}\text { Difference } \\
(\%)\end{array}$ & $P$ \\
\hline TSR & & & & \\
Oak & 0.32 & 0.34 & 5 & 0.3584 \\
Beech & 0.25 & 0.33 & 27 & 0.0001 \\
MSR & & & & \\
Oak & 0.18 & 0.27 & 43 & $<0.0001$ \\
Beech & 0.15 & 0.17 & 10 & 0.3143 \\
FFR & & & & \\
Oak & 0.15 & 0.07 & -74 & 0.0003 \\
Beech & 0.10 & 0.16 & 46 & 0.0050 \\
\hline
\end{tabular}

Table V. Annual contributions to soil respiration estimated for the field measurement period (16 November 2002 to 15 November 2003). The fluxes are expressed in $\mathrm{g} \mathrm{C} \mathrm{m}^{-2} \mathrm{y}^{-1}$ and were computed from the models (Tab. III) using temperature time series. $\Delta 1=\mathrm{MSR}-\mathrm{Ah}$ decomposition, $\Delta 2=$ FFR - FF decomposition.

\begin{tabular}{lccccccc}
\hline Stand & TSR & MSR & FFR & Ah decomp. & FF decomp. & $\Delta 1$ & $\Delta 2$ \\
\hline Oak & 922 & 634 & 257 & 215 & 174 & 419 & 83 \\
Mixture & 770 & 535 & 232 & 192 & 171 & 343 & 61 \\
Beech & 820 & 440 & 377 & 143 & 192 & 297 & 184 \\
\hline
\end{tabular}

modality until day 202 of 2003 at which all curves joined and continued their temporal variation together (Fig. 1c).

\subsection{Temperature effect}

In situ, the TSR at $10{ }^{\circ} \mathrm{C}\left(R_{10}\right.$ in Tab. III) was higher under oak than under mixture and beech while the TSR temperature sensitivity ( $Q_{10}$ in Tab. III) was higher under beech than under oak and mixture (Fig. 2). Concerning MSR, the differences in $Q_{10}$ between stands were not statistically significant; only the $R_{10}$ was affected by stand and decreased in the order: oak $>$ mixture $>$ beech. For FFR, the $R_{10}$ was higher under beech than under mixture and oak. In addition, we observed a higher $Q_{10}$ under beech than under oak and mixture; however, this difference was not significant, given the large variability of FFR.

In the laboratory, the respiration rate at $10{ }^{\circ} \mathrm{C}\left(R_{10}\right)$ and the temperature sensitivity $\left(Q_{10}\right)$ of the forest floor and Ah horizons were lower than those of the corresponding in situ horizons (Tab. III). Concerning the Ah incubations, the $R_{10}$ decreased in the order: oak $>$ mixture $>$ beech, while the $Q_{10}$ was not influenced by stand composition. The $R_{10}$ of the forest floor respiration was higher for the beech than for the oak and mixed stands while the trend was reversed for $Q_{10}$ (Tab. III).
Table VI. Carbon budget in the forest floor of the three stands, assuming the steady state (fluxes expressed in $\mathrm{g} \mathrm{C} \mathrm{m}^{-2} \mathrm{y}^{-1}$ ). The annual $\mathrm{CO}_{2}$ release derived from the forest floor decomposition was computed for 1996 , a normal year for the air temperature $\left(8.4^{\circ} \mathrm{C}\right) . \Delta=$ total litterfall - (forest floor decomposition + DOC).

\begin{tabular}{lcccc}
\hline Stand & $\begin{array}{c}\text { Total } \\
\text { litterfall }\end{array}$ & $\begin{array}{c}\text { Forest floor } \\
\text { decomposition }\end{array}$ & DOC & $\Delta$ \\
\hline Oak & 215 & 151 & 17 & 47 \\
Mixture & 206 & 152 & 19 & 35 \\
Beech & 209 & 176 & 17 & 16 \\
\hline
\end{tabular}

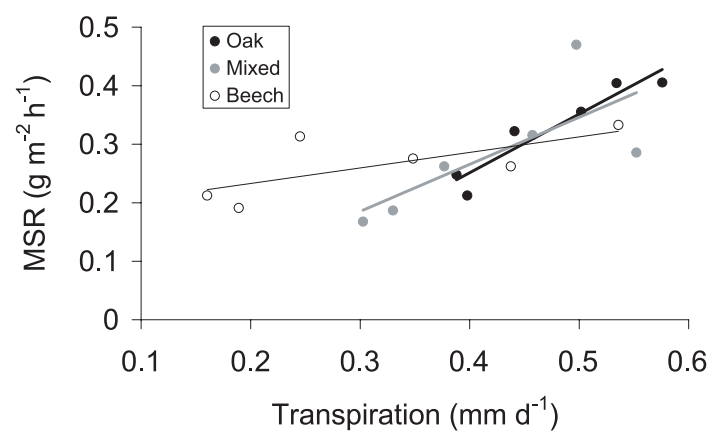

Figure 3. Relationship between MSR and tree transpiration of the previous day during the growing period for the three stands. Transpiration data were obtained from a model developed in a study carried out on the same site during the 2003 growing season (François Jonard, unpublished data). Lines represent linear regression.

\subsection{Soil water content effect}

The soil water content effect on in situ soil respiration was assessed by comparing the two extreme moisture modalities (Tab. IV) and by analysing the measurements of Period 2 (days 155 to 229 of 2003) during which soil water content decreased progressively while high soil temperatures were maintained (Fig. 1).

In the oak stand, the moisture treatment did not affect TSR while MSR and FFR were respectively lower and higher in the dry modality. In the beech stand, the lower TSR in the dry modality was associated with lower FFR, MSR being unaffected by the moisture treatment (Tab. IV).

From days 155 to 229 of 2003 (Period 2, Fig. 1), soil temperatures varied between 14 and $16{ }^{\circ} \mathrm{C}$ while soil water content decreased from 0.30 to $0.15 \mathrm{~m}^{3} \mathrm{~m}^{-3}$. This change in soil water content did not affect TSR and FFR while MSR varied along the soil water content range according to a quadratic relationship (Fig. 2). The effect of soil water content on MSR followed different patterns according to stand composition and was more pronounced under oak $>$ mixture $>$ beech.

\subsection{Annual fluxes and forest floor carbon budget}

The annual TSR of the oak stand was on average $16 \%$ higher compared with those of the mixed and beech stands; the annual MSR decreased strongly in the order: oak > mixture > beech; the annual FFR was $50 \%$ higher under beech 
than under the mixed and oak stands which showed similar annual FFRs (Tab. V). FFR accounted respectively for 28, 30 and $46 \%$ of TSR in the oak, mixed and beech stands.

The annual heterotrophic respiration of the forest floor accounted respectively for 68,74 and $51 \%$ of the annual FFR in the oak, mixed and beech stands (Tab. V). In the mineral soil, the annual heterotrophic respiration of the Ah horizon represented respectively 34,36 and $33 \%$ of MSR in the oak, mixed and beech stands (Tab. V).

Assuming that the equilibrium stage was reached, the fluxes regulating the carbon stock of the forest floor were estimated for 1996, an average year for air temperature (Tab. VI). Based on the laboratory incubations, we calculated that the equivalent of 70, 74 and $84 \%$ of the annual carbon input by litterfall were released annually by heterotrophic respiration and that 8 , 9 and $8 \%$ were leached as DOC in the oak, mixed and beech stands, respectively.

\section{DISCUSSION}

\subsection{Temperature effect}

In this study, we used the $Q_{10}$ function to compare the temperature sensitivity of soil respiration contributions in stands differing in their species composition. However, $Q_{10} \mathrm{~s}$ estimated from annual datasets do not solely reflect the true temperature sensitivity of soil respiration, they also result from the multiplicative effects of several processes whose seasonality may be in phase or out of phase with the temporal variations in temperature $[12,13,28]$.

The $Q_{10}$ s of TSR calculated for the three stands (Tab. III) fall within the range (2.0-6.3) reported for European and North-American forest ecosystems [14, 28]. Under beech, the TSR $Q_{10}$ is at the higher end of the range (2.7-4.6) reported for European beech forests [7,21,28], while the TSR $Q_{10}$ under oak is close to the value (3.25) reported in the study of Curiel et al. [12] for pedonculate oak. Concerning the laboratory incubation of the Ah horizon, the $Q_{10}$ s correspond well to the findings of Winkler et al. [44] who incubated the Ah horizon of a forest soil and obtained $Q_{10}$ s varying between 1.9 and 1.7 over a temperature range of 4 to $28^{\circ} \mathrm{C}$.

Compared with the $Q_{10}$ s derived from the field measurements, the lower $Q_{10}$ s obtained in the laboratory could be due to the fact that rhizosphere respiration was not taken into account. Among others, Boone et al. [6] reported a higher $Q_{10}$ for rhizosphere respiration (4.6) than for soil respiration excluding roots (2.5); however, the higher $Q_{10}$ for rhizosphere respiration most likely results from the multiplicative effects of several processes: enzyme activity, root growth and photosynthate production. On another hand, Subke et al. [42] showed that rhizosphere activity increases litter respiration, possibly by simulating microbial activity through the addition of easily accessible carbon (soil priming).

Compared with the oak and mixed stands, the higher TSR $Q_{10}$ of the beech stand is associated with a larger FFR $Q_{10}$ (Tab. III). However, this higher FFR $Q_{10}$ is not due to the heterotrophic respiration whose $Q_{10}$ decreases in the order: oak > mixture $>$ beech (laboratory incubations, Tab. III). The higher
TSR and FFR $Q_{10}$ under beech might be explained by the shallower rooting pattern of this species (Tab. I); this could indeed increase the temperature sensitivity of rhizosphere respiration since superficial roots are more exposed to temperature variations.

\subsection{Soil water content effect}

The contrasting response of the oak and beech stands to the moisture treatment (Tab. IV) could be due to differences in the water storage capacity of the forest floor. The thicker forest floor developed under beech (Tab. II) retains more water than the thin oak forest floor. Consequently, the additional water inputs to the moist modality were probably absorbed by the forest floor under beech while they were rapidly leached through the thin forest floor under oak and were thus more beneficial to the mineral soil in this stand. This could partly explain why the difference between the moist and the dry modalities was positive for FFR under beech and for MSR under oak (Tab. IV). The FFR decrease under dry conditions in the beech stand is in agreement with the reduced decomposition rate of beech leaves exposed to the same moisture treatment in this site [31]. Low soil water content may indeed reduce microbial activities by limiting the diffusion of soluble organic substrates [21,39]. In contrast, the increased FFR under dry conditions in the oak stand is quite surprising since the decomposition rate of oak leaves was reduced by drought [31]. This unexpected effect of the moisture treatment under oak could be an artefact associated with the large spatial variability and with the fact that FFR was obtained by difference (TSR-MSR). Since TSR was not significantly affected by the moisture treatment under oak, the apparent positive effect on MSR probably brought about the negative effect on FFR. It is indeed quite unlikely that the moisture treatment influenced MSR to such an extent knowing that rhizosphere respiration is certainly the main contribution to MSR and that the watered areas were small compared with the root-prospecting area of a tree. In this experiment, the moisture treatment affected most likely only the heterotrophic respiration. Artefacts could have been produced by the forest floor removal. Indeed, the forest floor is a boundary layer limiting $\mathrm{CO}_{2}$ diffusion, especially when the litter is wet [15]. Removal of this layer could have caused a "chimney" effect, thus potentially resulting in an overestimation of MSR, especially in the moist modality. However, as this property of the forest floor is more marked for large litter accumulations, the artefact should have been more pronounced under beech, which was not the case.

During Period 2 exhibiting high temperatures and decreasing soil water content (Fig. 1), we observed a significant effect of soil water content only on MSR and this effect appeared to be more pronounced under oak $>$ mixture $>$ beech (Fig. 2). The lack of effect under beech could be due to its thicker forest floor which probably limited the water inputs to the mineral soil by absorbing most of the rainfall [34]; it could also be ascribed to higher root mortality during the summer drought, given the shallower rooting pattern of this species.

The absence of soil water content effect on TSR and FFR (Period 2) is probably linked to the fact that the range of soil 
water content did not extend to very low values. Indeed, Rey et al. [39] reported that soil water content strongly limited soil respiration only when its value dropped below $0.20 \mathrm{~m}^{3} \mathrm{~m}^{-3}$ over $0-10 \mathrm{~cm}$ depth. Since TDR probes are not able to measure soil moisture in organic horizons, measurements of soil water content were carried out in the upper hemiorganic horizon; this could have led to additional variability when related to FFR due to either differences in hydrological properties between the two soil layers [34] or to temporal decoupling.

\subsection{Annual fluxes and forest floor carbon budget}

The annual TSRs under oak, mixture and beech (Tab. V) were higher than the mean annual soil respiration reported by Raich and Schlesinger [38] for temperate deciduous forests $\left(647 \pm 275 \mathrm{~g} \mathrm{C} \mathrm{m}^{-2} \mathrm{y}^{-1}\right)$ and by Janssens et al. [29] for European forest $\left(760 \pm 340 \mathrm{~g} \mathrm{C} \mathrm{m}^{-2} \mathrm{y}^{-1}\right)$; however, our values fall within their $95 \%$ confidence intervals. In this study, the annual TSR under beech (Tab. V) is beyond the upper end of the range (489-620 $\mathrm{g} \mathrm{C} \mathrm{m}^{-2} \mathrm{y}^{-1}$ ) reported for European beech forest [1, 7, 21].

The heterotrophic respiration in the forest floor accounted respectively for 19, 22 and $23 \%$ of TSR under oak, mixture and beech (Tab. V). These proportions agrees totally with those obtained by Rey et al. [39], who estimated that decomposition of aboveground litter contributed to $22 \%$ of TSR in an oak coppice in Central Italy. Similar proportions were obtained in earlier studies attempting to partition soil respiration $[15,16,22]$.

Both contributions to TSR (MSR and FFR) were influenced by stand composition. These differences between stands cannot be attributed to ground climate, which was similar in the three stands (Fig. 1). The higher annual MSR under oak compared with beech is partly explained by the higher heterotrophic respiration of the Ah horizon (Tab. V); it could also be due to differences in the response to soil water content variations (see Sect. 3.4) and/or the contrasting behavior of oak and beech in response to drought stress. In a study on tree transpiration conducted at our experimental site in 2003, it was observed that tree transpiration was more limited by drought in the beech than in the oak stand (François Jonard, unpublished data). As photosynthesis and transpiration are coupled through the activity of stomata, we supposed that more photosynthates were produced and allocated to roots in the oak stand resulting in higher rhizosphere respiration. This is consistent with the study of Leuschner et al. [36] who found oak to be more drought-tolerant than beech; they reported that oak maintains a higher leaf conductance and photosynthetic activity, and is less vulnerable to cavitation during drought. Figure 3 illustrates the correlation between MSR and the tree transpiration of the previous day for the three stands.

The annual FFR was higher under beech than under mixture and oak, but this stand effect cannot be explained only by the annual heterotrophic respiration of the forest floor (Tab. V); it could also be ascribed to a higher rhizosphere respiration in the beech forest floor. However, the root biomass of the forest floor (Tab. II) was not sufficient to account for the difference between the annual FFR and the annual heterotrophic respiration of the forest floor $(\Delta 2$, Tab. V). Indeed, considering that total root biomass amounted to $250 \mathrm{~g} \mathrm{~m}^{-2}$ in all stands [35] and that $52 \%$ of TSR originated from total rhizosphere respiration [20], we estimated the rhizosphere respiration in the forest floor on the basis of the root biomass measured in this horizon and obtained only 4, 20 and $25 \mathrm{~g} \mathrm{C} \mathrm{m}^{-2} \mathrm{y}^{-1}$ respectively under oak, mixture and beech. Comparable estimates (4, 26 and $32 \mathrm{~g} \mathrm{C} \mathrm{m}^{-2} \mathrm{y}^{-1}$ ) were obtained using the root biomass of the forest floor, the soil temperature time series of the measurement period and the equation of Gansert [24] describing the temperature dependence of beech fine root respiration. The unexplained remaining difference has two possible sources: the use of two different methods to measure the $\mathrm{CO}_{2}$ fluxes and the priming effect. Recent inter-comparison studies have shown that the type of chamber we used in the field (SRC-1, PP Systems) measures higher fluxes compared with other methods, including the absorption alkali method we used in the laboratory $[30,33]$. On the other hand, part of the remaining difference could be due to soil priming (see Sect. 4.1).

The main input to the forest floor is litterfall and the outputs are $\mathrm{CO}_{2}$ release derived from litter decomposition and solid or soluble transfers to the mineral soil (Tab. VI). The difference between total litterfall and forest floor decomposition plus DOC leaching was greater under oak and mixture than under beech. This difference suggests either that the steady state had not been reached in the oak and mixed stands or that solid transfers were occurring there due to a greater soil fauna activity. In support of the latter hypothesis, Cortez [11] reported that earthworms find oak leaf litter more palatable; therefore, larger quantities of fresh organic matter could be mixed into the Ah horizon under oak, resulting in a larger Ah horizon (Tab. II) and greater organic matter decomposition in the Ah horizon (Tab. III).

This study is the first attempt to understand how species composition influences the various contributions to soil respiration. We have shown that stand composition may have an important impact on these contributions and on their relationship with the abiotic factors. However, further studies are needed to improve our knowledge of this relatively unexplored field.

Acknowledgements: This study was initiated by the Forest Service of the Walloon Region (Division de la Nature et des Forêts, DNF, Belgium) and funded by the Regional Ministry of Agriculture through the project "Accord-Cadre Recherches Forestières". We would like to thank S. Caja for her collaboration, and F. Hardy and F. Plume for their intensive help with fieldwork. This manuscript was greatly improved by the constructive criticism of two anonymous reviewers.

\section{REFERENCES}

[1] Anderson J.M., Carbon dioxide evolution from two temperate, deciduous woodland soils, J. Appl. Ecol. 10 (1973) 361-378.

[2] Augusto L., Ranger J., Binkley D., Rothe A., Impact of several common tree species of European temperate forests on soil fertility, Ann. For. Sci. 59 (2002) 233-253.

[3] Bhupinderpal-Singh, Nordgren A., Ottosson-Löfvenius M., Högberg M.N., Mellander P.E., Högberg P., Tree root and soil 
heterotrophic respiration as revealed by girdling of boreal Scots pine forest: extending observations beyond the first year, Plant Cell Environ. 26 (2003) 1287-1296.

[4] Binkley D., The influence of tree species on forest soils: processes and patterns, in: Mead D.J., Cornforth I.S. (Eds.), Proceedings of the Trees and Soil Workshop, Lincoln University press, Canterbury, New Zealand, 1995, pp. 1-34.

[5] Blet-Charaudeau C., Muller J., Laudelout H., Kinetics of carbon dioxide evolution in relation to microbial biomass and temperature, Soil Sci. Soc. Am. J. 54 (1990) 1324-1328.

[6] Boone R.D., Nadelhoffer K.J., Canary J.D., Kaye J.P., Roots exert a strong influence on the temperature sensitivity of soil respiration, Nature 396 (1998) 570-572.

[7] Borken W., Xu Y.J., Davidson E.A., Beese F., Site and tempora variation of soil respiration in European beech, Norway spruce, and Scots pine forests, Global Change Biol. 8 (2002) 1205-1216.

[8] Bowden R.D., Nadelhoffer K.J., Boone R.D., Melillo J.M., Garrison J.B., Contributions of above-ground litter, below-ground litter, and root respiration to total soil respiration in a temperate mixed hardwood forest, Can. J. For. Res. 23 (1993) 1402-1407.

[9] Bray J.R., Gorham E., Litter production in forests of the world, Adv. Ecol. Res. 2 (1964) 101-157.

[10] Carlisle A., Brown A.H.F., White E.J., Litter fall, leaf production, and the effects of defoliation by Tortrix viridana in a sessile oak (Quercus petraea) woodland, J. Ecol. 54 (1966) 65-85.

[11] Cortez J., Field decomposition of leaf litters: relationships between decomposition rates and soil moisture, soil temperature and earthworm activity, Soil Biol. Biochem. 30 (1998) 783-793.

[12] Curiel Yuste J., Janssens I.A., Carrara A., Ceulemans R., Annual $Q_{10}$ of soil respiration reflects plant phenological patterns as well as temperature sensitivity, Global Change Biol. 10 (2004) 161-169.

[13] Davidson E.A., Janssens I.A., Luo Y., On the variability of respiration in terrestrial ecosystems: moving beyond $Q_{10}$, Global Change Biol. 12 (2006) 154-164.

[14] Davidson E.A., Belk E., Boone R.D., Soil water content and temperature as independent or confounded factors controlling soil respiration in a temperate mixed hardwood forest, Global Change Biol. 4 (1998) 217-227.

[15] Edwards N.T., Effects of temperature and moisture on carbon dioxide evolution in a mixed deciduous forest floor, Soil Sci. Soc. Am. J. 39 (1975) 361-365.

[16] Edwards N.T., Harris W.F., Carbon cycling in a mixed deciduous forest floor, Ecology 58 (1977) 431-437.

[17] Edwards N.T., Sollins P., Continuous measurement of carbon dioxide evolution from partitioned forest floor components, Ecology 54 (1973) 406-412.

[18] Ekblad A., Högberg P., Natural abundance of ${ }^{13} \mathrm{C}$ in $\mathrm{CO}_{2}$ respired from forest soils reveals speed of link between tree photosynthesis and root respiration, Oecologia 127 (2001) 305-308.

[19] Ekblad A., Boström B., Holm A., Comstedt D., Forest soil respiration rate and $\delta^{13} \mathrm{C}$ is regulated by recent above ground weather conditions, Oecologia 143 (2005) 136-142.

[20] Epron D., Le Dantec V., Dufrene E., Granier A., Seasonal dynamics of soil carbon dioxide efflux and simulated rhizosphere respiration in a beech forest, Tree Physiol. 21 (2001) 145-152.

[21] Epron D., Farque L., Lucot E., Badot P.M., Soil $\mathrm{CO}_{2}$ efflux in a beech forest: dependence on soil temperature and soil water content, Ann. For. Sci. 56 (1999) 221-226.

[22] Ewel K.C., Cropper W.P., J.R., Gholz H.L., Soil $\mathrm{CO}_{2}$ evolution in Florida slash pine plantations. II. Importance of root respiration, Can. J. For. Res. 17 (1987) 330-333.
[23] Fang C., Moncrieff J.B., The dependence of $\mathrm{CO}_{2}$ efflux on temperature, Soil Biol. Biochem. 33 (2001) 155-165.

[24] Gansert D., Root respiration and its importance for the carbon balance of beech saplings (Fagus sylvatica L.) in a montane beech forest, Plant Soil 167 (1994) 109-119.

[25] Hanson P.J., Edwards N.T., Garten C.T., Andrews J.A., Separating root and soil microbial contributions to soil respiration: a review of methods and observations, Biogeochemistry 48 (2000) 115-146.

[26] Högberg P., Nordgren A., Buchmann N., Taylor A.F.S., Ekblad A., Högberg M.N., Nyberg G., Ottosson-Löfvenius M., Read D.J., Large-scale forest girdling shows that current photosynthesis drives soil respiration, Nature 411 (2001) 789-792.

[27] Jabiol B., Brêthes A., Ponge J.F., Toutain F., Brun J.J., L'humus sous toutes ses formes, Engref, Nancy, France, 1995, 64 p.

[28] Janssens I.A., Pilegaard K., Large seasonal changes in $Q_{10}$ of soil respiration in a beech forest, Global Change Biol. 9 (2003) 911918.

[29] Janssens I.A., Lankreijer H., Matteucci G., Kowalski A.S., Buchmann N., Epron D., Pilegaard K., Kutsch W., Longdoz B., Grünwald T., Montagnani L., Dore S., Rebmann C., Moors E.J., Grelle A., Rannik Ü, Morgenstern K., Oltchev S., Clement R., Gudmundsson J., Minerbi S., Berbigier P., Ibrom A., Moncrieff J., Aubinet M., Bernhofer C., Jensen N.O., Vesala T., Granier A., Schulze E.D., Lindroth A., Dolman A.J., Jarvis P.G., Ceulemans R., Valentini R., Productivity overshadows temperature in determining soil and ecosystem respiration across European forests, Global Change Biol. 7 (2001) 269-278.

[30] Janssens I.A., Kowalski A.S., Longdoz B., Ceulemans R., Assessing forest soil $\mathrm{CO}_{2}$ efflux: an in situ comparison of four techniques, Tree Physiol. 20 (2000) 23-32.

[31] Jonard M., Dynamique des litières foliaires en peuplements purs et mélangés de chêne et de hêtre. Retombées foliaires et premières étapes de la décomposition, Ph.D. thesis, UCL, Faculté d'ingénierie biologique, agronomique et environnementale, CIACO, Louvainla-Neuve, Belgique, 2005, 205 p.

[32] Lebret M., Nys C., Forgeard F., Litter production in an Atlantic beech (Fagus sylvatica L.) time sequence, Ann. For. Sci. 58 (2001) $755-768$.

[33] Le Dantec V., Epron D., Dufrêne E., Soil $\mathrm{CO}_{2}$ efflux in a beech forest: comparison of two closed dynamic systems, Plant Soil 214 (1999) 125-132.

[34] Leuschner C., Water extraction by tree fine roots in the forest floor of a temperate Fagus-Quercus forest, Ann. Sci. For. 55 (1998) 141157.

[35] Leuschner C., Hertel D., Coners H., Büttner V., Root competition between beech and oak: a hypothesis, Oecologia 126 (2001) 276284.

[36] Leuschner C., Backes K., Hertel D., Schipka F., Schmitt U., Terborg O., Runge M., Drought responses at leaf, stem and fine root levels of competitive Fagus sylvatica L. and Quercus petraea (Matt.) Liebl. trees in dry and wet years, For. Ecol. Manage. 149 (2001) 33-46.

[37] Lloyd J., Taylor J.A., On the temperature dependence of soil respiration, Funct. Ecol. 8 (1994) 315-223.

[38] Raich J.W., Schlesinger W.H., The global carbon dioxide flux in soil respiration and its relationship to vegetation and climate, Tellus 44B (1992) 81-99.

[39] Rey A., Pegoraro E., Tedeschi V., De Parri I., Jarvis P.G., Valentini R., Annual variation in soil respiration and its components in a coppice oak forest in Central Italy, Global Change Biol. 8 (2002) 851866. 
[40] Rothe A., Binkley D., Nutritional interactions in mixed species forests: a synthesis, Can. J. For. Res. 31 (2001) 1855-1870.

[41] Rout S.K., Gupta S.R., Soil respiration in relation to abiotic factors, forest floor litter, root biomass, and litter quality in forest ecosystems of Siwaliks in northern India, Acta Oecol. 10 (1989) 229-244.

[42] Subke J.A., Hahn V., Battipaglia G., Linder S., Buchmann N., Cotrufo M.F., Feedback interactions between needle litter decomposition and rhizosphere activity, Oecologia 139 (2004) 551-559.
[43] Vogt K.A., Vogt D.J., Palmiotto P.A., Boon P., O'Hara J., Asbjornsen H., Review of root dynamics in forest ecosystems grouped by climate, climatic forest type and species, Plant Soil 187 (1996) 159-219.

[44] Winkler J.P., Cherry R.S., Schlesinger W.H., The $Q_{10}$ relationship of microbial respiration in a temperate forest soil, Soil Biol. Biochem. 28 (1996) 1067-1072.

[45] Woodwell G.M., Mackenzie F.T., Houghton R.A., Apps M., Gorham E., Davidson E., Biotic feedbacks in the warming of the earth, Climatic Change 40 (1998) 495-518. 